\title{
KENDALA IMPLEMENTASI KURIKULUM 2013 DALAM PEMBELAJARAN BAHASA JEPANG DI SMAN 2 SINGARAJA DAN SMAN 4 SINGARAJA
}

\author{
E. M. APRIANII, K. E. K. ADNYANI ${ }^{2}$, N.N. SUARTINI ${ }^{3}$ \\ ${ }^{123} J u r u s a n$ Bahasa Asing, Universitas Pendidikan Ganesha, Singaraja \\ e-mail: monifaevy@gmail.com, krishna.adnyani@undiksha.ac.id, nnsuartini@undiksha.ac.id
}

\begin{abstract}
Abstrak
Penelitian ini bertujuan menganalisis kendala guru bahasa Jepang dalam mengimplementasikan Kurikulum 2013, faktor kendala serta upaya guru untuk mengatasi kendala tersebut. Penelitian ini menggunakan teori implementasi Kurikulum 2013. Metode pengumpulan data yang digunakan adalah metode wawancara, observasi, dan dokumentasi. Data yang dikumpulkan dikelompokkan sesuai rumusan masalah dan dianalisis dengan metode analisis deskriptif kualitatif. Hasil penelitian yaitu guru mengalami kendala dalam menciptakan pembelajaran yang berpusat pada siswa, menentukan model pembelajaran, merancang langkah pembelajaran, menyiapkan media pembelajaran, keterbatasan buku ajar, menerapkan pendekatan saintifik, dan melakukan asesmen Kurikulum 2013. Faktornya adalah penggunaan media ajar belum maksimal, ketersediaan sarana prasarana, guru terbiasa mengajar dengan kurikulum lama, keterbatasan penguasaan bahasa Jepang, karakteristik siswa, jumlah siswa, keterbatasan waktu, keaktifan siswa, banyaknya jenis asesmen, dan beban kerja guru yang besar. Upaya yang dilakukan adalah memerhatikan pedoman Kurikulum 2013, mencari materi di sumber lainnya, pemanfaatan teknologi secara optimal dan melakukan penilaian secara bergantian.
\end{abstract}

Kata kunci: faktor, kendala, implementasi, Kurikulum 2013, upaya

要旨

本研究の目的は 2013 年のカリキュラムを実施する際に日本語教師が直面する問題を明らかにする。その 要因、その問題の解決方法明らかにする。研究では 2013 年のカリキュラムの実装を使用している。デー タは、半構造化インタビュー、観察、資料によって収取、記述的定性分析法で分析しである。結果は、教 師が学生中心の学習方法に問題がある, 学習モデルの選ぶ、学習活動を設計する、学習媒体の準備、限定 書籍、科学的アプローチを適用寸る、2013 年のカリキュラムの評価。その要因は教育用メディアの使用、 施設の可用性、教師は古いカリキュラムで教えることに慣れている、学生がマスターする日本語の限界、 学生の特徴、学生数、時間の制約、学生の無活動、2013 年のカリキュラムの評価の多くのタイプ、大き な教師の作業負荷。問題の解決方法は 2013 年のカリキュラムのガイドラインに注意を払う、他の本の資 料を探している、技術を最大限に活用をする、各会議で異なる学生を評価する。

キーワード : 2013 年のカリキュラム、実施、問題、問題の解決方法、要

\section{Pendahuluan}

Selain pendidikan non formal yang diperoleh dari lingkungan keluarga, juga ada pendidikan formal yang terjadi di sekolah. Pendidikan yang terjadi di sekolah dilandaskan pada kurikulum. Kurikulum adalah seperangkat rencana dan pengaturan mengenai tujuan, isi dan bahan pelajaran, serta cara yang digunakan sebagai pedoman penyelenggaraan kegiatan pembelajaran untuk mencapai tujuan pendidikan tertentu (UU No. 20, 2003).

Karena pendidikan memiliki peran yang penting, banyak usaha yang dilakukan pemerintah untuk meningkatkan kualitas pendidikan di Indonesia. Salah satunya dengan diperbaharuinya kurikulum pendidikan yang diharapkan berdampak baik untuk kualitas sumber daya manusia. Pengembangan kurikulum dapat dibuat lebih efektif dengan dikembangkannya aspek-aspek seperti materi pembelajaran, rencana pembelajaran, dan strategi pembelajaran (Panikar, 2015).

Tahun ajaran 2013/2014, pemerintah menguji coba kurikulum baru, yaitu Kurikulum 2013. Sekolah yang dipilih untuk melaksanakan Kurikulum 2013 adalah sekolah tingkat SD, SMP, dan SMA/SMK. Dalam Modul Pelatihan Kurikulum 2013, dinyatakan bahwa Kurikulum 2013 
dikembangkan berdasarkan faktor-faktor seperti tantangan internal, tantangan eksternal, penyempurnaan pola pikir, penguatan tata kelola kurikulum, dan penguatan materi. Fokus dari penerapan Kurikulum 2013 adalah mendorong siswa untuk lebih mampu dalam proses observasi, menanya, mencoba, mengasosiasi, dan mengomunikasikan pelajaran yang diperoleh di dalam kelas (Anwar, 2014).

Meskipun pemerintah telah mengembangkan kurikulum baru, tapi Kurikulum 2013 belum diterapkan di semua sekolah. Banyak sekolah yang masih menerapkan KTSP dikarenakan guru maupun pihak sekolah menghadapi kendala dalam implementasi Kurikulum 2013. Pada tahun ajaran 2017/2018, terdapat empat sekolah yang sudah menerapkan Kuriulum 2013 pada semua jenjang kelas, anatara lain SMAN 1 Singaraja, SMAN 2 Singaraja, SMAN 3 Singaraja dan SMAN 4 Singaraja. Dari observasi awal yang dilakukan, dipilih dua sekolah yang menjadi lokasi dalam penelitian ini, yaitu SMAN 2 dan SMAN 4 Singaraja.

Dari pengalaman yang dilakukan selama dilaksanakannya PPL-Real di SMAN 4 Singaraja, implementasi Kurikulum 2013 dalam pembelajaran bahasa Jepang masih menghadapi kendala. Selama PPL-Real berlangsung, memang ditemukan kendala dalam menjadikan siswa menjadi lebih aktif. Untuk itu diperlukan usaha yang lebih agar siswa menjadi lebih aktif dalam pembelajaran.

SMAN 4 Singaraja merupakan salah satu sekolah di Singaraja yang telah menerapkan Kurikulum 2013. Sejak Kurikulum 2013 diterapkan di Indonesia, Kurikulum 2013 juga digunakan di SMAN 4 Singaraja untuk semua mata pelajaran termasuk mata pelajaran bahasa Jepang. Tetapi, meskipun Kurikulum 2013 telah diterapkan SMAN 4 Singaraja sejak tahun ajaran 2013/2014, masih ditemukan kendala dalam pelaksanaannya.

Berdasarkan wawancara awal yang dilakukan di SMAN 2 Singaraja, diketahui bahwa SMAN 2 merupakan sekolah yang mengalami perubahan kurikulum dari KTSP menjadi Kurikulum 2013. SMAN 2 merupakan salah satu sekolah yang ditunjuk pemerintah sebagai pilot project. Guru SMAN 2 Singaraja mengaku mengalami kesulitan dalam menerapkan Kurikulum 2013. Misalnya dalam pembuatan RPP, menerapkan pendekatan ilmiah (scientific approach), dan menerapkan penilaian yang sesuai dengan Kurikulum 2013. Karena temuan ini cocok dengan permasalahan yang diteliti, maka SMAN 2 Singaraja dipilih menjadi salah satu lokasi penelitian.

Berdasarkan uraian di atas, diadakan penelitian tentang kendala implementasi Kurikulum 2013 dalam pembelajaran bahasa Jepang. Selain itu, faktor-faktor penyebab kendala implementasi dan upaya yang dilakukan untuk mengatasi kendala implementasi Kurikulum 2013 juga menjadi tujuan dalam penelitian ini.

Alasan dilakukannya penelitian mengenai kendala dalam implementasi Kurikulum 2013 karena sejak Kurikulum 2013 mulai diterapkan di Indonesia, terdapat keluhan guru mengenai Kurikulum 2013. Hingga pemerintah memberi kebijakan kepada pihak sekolah untuk tidak menggunakan Kurikulum 2013 dan kembali ke kurikulum lama (Permendikbud No. 159, 2014). Karena itu implementasi Kurikulum 2013 merupakan hal yang masih menarik untuk diteliti. Saat ini Kurikulum 2013 sedang diterapkan dalam pendidikan Indonesia pada jenjang pendidikan dasar dan pendidikan menengah. Berbagai temuan yang dihasilkan melalui penelitian yang dilaksanakan dapat menjadi masukan dan pertimbangan bagi pemerintah dalam melaksanakan evaluasi Kurikulum 2013 yang berdampak pada peningkatan kualitas pendidikan. Karena dengan mengetahui kendala yang dihadapi guru, pembelajaran dengan Kurikulum 2013 dapat diperbaiki sehingga proses pembelajaran akan menjadi lebih efektif.

Kurikulum dapat didefinisikan melalui 4 kategori yaitu: konten pendidikan atau materipelajaran (educational content or subject matter), kegiatan yang direncanakan (planned activities), tugas dan konsep (tasks and concepts), dan hasil pembelajaran yang direncanakan (intended learningoutcomes).

Menurut Permendikbud Nomor 81 A tentang Implementasi Kurikulum 2013, kurikulum yang diterapkan dalam dunia pendidikan di Indonesia mulai tahun ajaran 2013/2014 adalah Kurikulum 
2013. Kurikulum 2013 merupakan langkah lanjutan pengembangan Kurikulum Berbasis Kompetensi yang telah dirintis pada tahun 2004 dan Kurikulum Tingkat Satuan Pendidikan 2006. Anwar (2014) berpendapat alasan lain dilakukannya perubahan kurikulum adalah kurikulum sebelumnya dianggap memberatkan peserta didik. Terlalu banyak materi pelajaran yang harus dipelajari oleh peserta didik, sehingga membuat siswa terbebani. Menurut Mendikbud (2013) bahwasanya pada dasarnya zaman selalu berubah. Oleh karena itu kurikulum pendidikan harus pula disesuaikan dengan perubahan dan tuntutan zaman. Saat ini yang dituntut adalah kurikulum yang lebih berbasis pada penguatan penalaran, bukan lagi hapalan semata.

Kurikulum 2013 mulai diterapkan secara bertahap di Indonesia mulai tahun ajaran 2013/2014. Penerapan Kurikulum 2013 sebagai kurikulum baru tentunya memiliki perbedaan dalam pelaksanaannya.

Dalam Permendikbud No 65 tahun 2013 dijelaskan bahwa pembelajaran dengan Kurikulum 2013 menggunakan pendekatan ilmiah (scientific approach) yang dalam prosesnya diutamakan keterlibatan siswa melalui kegiatan 5M (menyimak, menanya, mengumpulkan informasi, mengasosiasi, dan mengomunikasikan). Berdasarkan prinsip di atas, proses pembelajaran dengan Kurikulum 2013 dibagi menjadi tiga tahapan yaitu, perencanaan pembelajaran, pelaksanaan pembelajaran, dan penilaian proses pembelajaran.

Dijelaskan bahwa perencanaan pembelajaran dirancang dalam bentuk silabus dan Rencana Pelaksanaan Pembelajaran (RPP) yang mengacu pada Standar Isi. Perencanaan pembelajaran meliputi penyusunan rencana pelaksanaan pembelajaran, penyiapan media dan sumber belajar, perangkat penilaian pembelajaran, dan skenario pembelajaran

Tahap kedua dalam pembelajaran menurut standar proses yaitu pelaksanaan pembelajaran. Alokasi waktu yang diberikan dalam proses pembelajaran pada jenjang SMA adalah 45 menit tiap 1 jam pelajaran. Dalam Permendikbud No. 65 tahun 2013 tentang Standar Proses Pendidikan Dasar dan Menengah dijelaskan bahwa proses pelaksanaan pembelajaran dibagi menjadi kegiatan pendahuluan, inti dan penutup.

Dalam kegiatan pendahuluan, dapat diawali dengan memerhatikan kesiapan siswa secara psikis dan fisik untuk mengikuti proses pembelajaran. Ketika melakukan hal ini, guru juga dapat memberikan motivasi untuk siswa.

Kegiatan selanjutnya dalam kegiatan pembelajaran adalah kegiatan inti. Dalam kegiatan inti digunakan model pembelajaran, metode pembelajaran, media pembelajaran, dan sumber belajar yang disesuaikan dengan karakteristik siswa dan mata pelajaran. Pendekatan yang digunakan di jenjang sekolah menengah atas dan sederajat adalah pendekatan ilmiah (scientific approach) (Permendikbud, No. 65, 2013).

Kegiatan terakhir dalam proses pembelajaran adalah penutup. Dalam kegiatan penutup, guru bersama-sama dengan siswa menyampaikan rangkuman ataupun simpulan tentang pembelajaran yang berlangsung saat itu. Dalam kegiatan penutup, guru dapat melakukan penilaian atau refleksi terhadap kegiatan yang sudah dilaksanakan.

Penilaian dalam Kurikulum 2013 dilakukan dengan penilaian autentik. Penilaian autentik adalah penilaian nyata dan dibuktikan dengan kinerja atau hasil yang telah dicapai oleh siswa. Penilaian autentik sifatnya berkelanjutan sejak mulai sampai akhir pembelajaran. Hal ini dilakukan untuk memperoleh informasi perkembangan peserta didik (Yani, 2013).

Penelitian relevan yang dilakukan adalah penelitian dari Rahayu (2015) tentang kendala guru bahasa Jepang di SMA Semarang dalam implementasi Kurikulum 2013. Teknik pengumpulan data dalam penelitian tersebut dilakukan dengan menggunakan angket dan wawancara pada guru. Pada metode penelitian digunakan angket tertutup yaitu, angket yang jawabannya sudah disediakan dan responden tinggal memilih jawaban yang sesuai. Ada 33 butir soal yang diajukan dalam angket penelitian tersebut. Sedangkan wawancara dilakukan untuk memperkuat pertanyaan yang ada pada angket. Tetapi, penelitian tersebut kurang terfokus karena membahas secara keseluruhan unsur pembelajaran. Sehingga, kendala guru 
dalam implementasi Kurikulum 2013 kurang dipaparkan secara mendalam. Selain itu tidak ada pembahasan tentang upaya yang dilakukan guru untuk menghadapi kendala yang dialami.

\section{Metode}

Pendekatan penelitian yang digunakan dalam penelitian ini adalah pendekatan deskriptif kualitatif. Dalam penelitian ini akan dideskripsikan tentang kendala implementasi Kurikulum 2013 dalam pembelajaran bahasa Jepang.

Penelitian ini dilakukan di kota Singaraja, yaitu di SMAN 2 Singaraja dan SMAN 4 Singaraja. Sumber data utama dalam penelitian ini adalah hasil wawancara dan hasil observasi yang dilakukan pada guru mata pelajaran bahasa Jepang di SMAN 2 Singaraja dan SMAN 4 Singaraja. Observasi dilakukan terhadap guru ketika proses belajar mengajar dengan Kurikulum 2013.

Metode pengumpulan data dalam penelitian ini dilakukan dengan 3 cara yaitu, wawancara, observasi, dan dokumentasi. Wawancara yang dilakukan yaitu wawancara semi terstruktur. Wawancara dilakukan dengan mengajukan pertanyaan yang berhubungan dengan kendala penerapan Kurikulum 2013 dalam pembelajaran bahasa Jepang. Observasi yang digunakan dalam penelitian ini adalah jenis partisipasi pasif (passive participations). Peneliti datang ke tempat berlangsungnya kegiatan orang yang diamati tetapi tidak ikut dalam kegiatan tersebut. Jadi, observasi dalam penelitian ini dilakukan dengan cara melakukan pengamatan dalam pembelajaran bahasa Jepang tanpa berpartisipasi dalam kegiatan tersebut.

Dalam penelitian ini, juga digunakan metode dokumentasi. Dalam melaksanakan metode dokumentasi, dikumpulkan dokumen dan data-data yang diperlukan dalam permasalahan penelitian. Dokumen yang digunakan dalam penelitian ini berupa silabus, RPP, bahan ajar, dan foto proses kegiatan pembelajaran.

Teknik analisis data yang digunakan dalam penelitian ini adalah model analisis interaktif Miles \& Hubermanmodelanalisis interaktif Miles \& Huberman (dalam Satori, 2011) terdiri dari reduksi data, display data, dan penarikan kesimpulan.

Dalam penelitian ini, digunakan triangulasi teknik dan triangulasi sumber sebagai teknik untuk pengecekan keabsahan data. Triangulasi teknik dalam penelitian ini dilakukan dengan 3 teknik yang berbeda, yaitu wawancara, observasi, dan dokumentasi. Triangulasi sumber dalam penelitian ini dilakukan dengan mencari data dari hasil wawancara dengansumber yang berbeda yaitu, guru bahasa Jepang dan Kepala Sekolah SMAN 2 Singaraja dan SMAN 4 Singaraja.

\section{Hasil dan Pembahasan}

Observasi pertama di SMAN 2 Singaraja dilakukan di kelas X BB2 pada hari Selasa, 18 Agustus 2017 jam ke 1-2. Ketika guru memasuki kelas, siswa mengucapkan salam "Ohayou Gozaimasu" dan dilanjutkan mengucapkan salam "Om Swastyastu" yang dipimpin oleh ketua kelas. Ketika mengajar hari itu, G1 tidak melakukan absensi dan tidak ada kegiatan fukushuu. Tujuan pembelajaran juga tidak disampaikan, guru langsung memulai pembelajaran dengan menyampaikan materi ajar. Buku yang digunakan adalah buku Sakura dari The Japan Foundation.

Guru menjelaskan cara memperkenalkan diri dengan bahasa Jepang diawali dengan kata hajimemashite dan diakhiri dengan douzo yoroshiku onegaishimasu. Selanjutnya siswa diberikan pola kalimat untuk memperkenalkan diri sendiri. Kemudian siswa diberikan contoh cara memperkenalkan diri dimulai dari kata hajimemashite, isi dan penutup. Pada kegiatan belajar hari itu tidak ada langkah mengamati dari 5M karena guru langsung memberikan kosakata serta pola kalimat cara untuk memperkenalkan diri.

Selain mengamati, kegiatan menanya juga tidak terjadi. Kegiatan menanya dari 5M umumnya terjadi untuk menanyakan pemahaman siswa setelah proses mengamati, tapi hal ini juga tidak terjadi. 
Setelah siswa diberikan materi tentang perkenalan diri sendiri, satu persatu siswa diminta untuk mencoba memperkenalkan diri dengan bahasa Jepang. Materi pelajaran dilanjutkan dengan memperkenalkan diri sebagai orang Bali atau orang Indonesia. Pada kegiatan pembelajaran ini, diketahui bahwa langkah mencoba dalam 5M sudah terjadi.

Kegiatan penutup pada pembelajaran hari itu diakhiri dengan salam "Om, Shanti Shanti Shanti, Om". Kegiatan pembelajaran yang dilaksanakan di kelas X BB 1 pada hari itu belum berpusat pada siswa (student centered), sebaliknya masih berpusat pada guru. Hal ini dapat dilihat dari peran guru yang lebih mendominasi dalam proses pembelajaran.

Observasi kedua dilakukan di kelas XI BB pada Sabtu, 26 Agustus 2017 jam ke 1. Siswa mengucapkan salam "Om Swastyastu" dan dilanjutkan mengucapkan salam selamat pagi. Guru tidak mempersiapkan media pembelajaran. Tema pelajaran adalah Shoukai yang artinya perkenalan. Guru tidak melakukan absensi dan tidak melakukan fukushuu. Tujuan pembelajaran tidak disampaikan. Buku yang digunakan adalah buku Nihongo 1 dari The Japan Foundation.

Kegiatan belajar dimulai dengan dituliskannya tema pelajaran di papan tulis dengan tulisan hiragana. Sub tema pertama yaitu cara menyebutkan tingkatan kelas dalam bahasa Jepang. Karena siswa sudah mengetahui cara menyebutkan angka dalam bahasa Jepang, siswa hanya diberikan tambahan nensei untuk menyatakan tingkatan kelas. Kemudian siswa diberikan pola kalimat untuk menyatakan diri sebagai anak SMA kelas 11. Pada pembelajaran hari itu, langkah mengamati dan menanya belum terjadi.

Siswa diberikan beberapa kalimat dalam bahasa Indonesia kemudian siswa diminta menerjemahkan kalimat tersebut sesuai dengan pola yang telah dipelajari. Jawaban yang diberikan siswa dituliskan di papan oleh guru kemudian guru mengonfirmasi kembali apakah kalimat tersebut sudah benar atau belum. Untuk kalimat selanjutnya, seorang siswa diminta langsung menuliskan hiragananya ke depan kelas. Pada pembelajaran hari itu, langkah mencoba sudah diterapkan G1 dalam pembelajaran.

Pelajaran dilanjutkan dengan ditunjuknya seorang siswa untuk memperkenalkan seorang temannya. Siswa tersebut menjawab dengan pola kalimat yang benar yaitu menambahkan kata kochira sebagai cara untuk memperkenalkan orang lain. Siswa kembali diberikan latihan untuk menerjemahan kalimat untuk memperkenalkan orang lain.

Siswa kembali dilatih dengan memberikan beberapa kalimat dalam bahasa Indonesia. Pada contoh kalimat tersebut selain memperkenalkan nama, siswa juga diminta memperkenalkan kelas dan nama sekolah orang lain. Setelah siswa dilatih dengan beberapa contoh kalimat, secara berpasangan siswa diminta untuk memperkenalkan temannya di depan kelas. Dari langkah pembelajaran tersebut, didapatkan hasil bahwa G1 sudah mencoba menerapkan langkah mengomunikasikan pada pembelajaran hari itu.

Selama proses latihan ini, bel berbunyi menandakan waktu pelajaran berakhir.

Kegiatan pembelajaran yang dilaksanakan di kelas X BB 1 pada hari itu belum berpusat pada siswa (student centered), sebaliknya masih berpusat pada guru. Hal ini dapat dilihat dari peran guru yang lebih mendominasi dalam proses pembelajaran.

Observasi ketiga dilakukan di kelas XII BB 2 pada hari Senin, 4 September 2017 dengan tema dekiru koto. Siswa mengucapkan salam "Om Swastyastu" dan dilanjutkan mengucapkan salam selamat siang dalam bahasa Jepang. Sebelum membahas tema, guru mengumumkan hasil ulangan yang masih banyak di bawah KKM. Guru meminta siswa untuk mengetahui apa yang menyebabkan siswa mendapat nilai rendah dan memotivasi siswa mengatasi hal tersebut. Pada tahap ini, kegiatan pendahuluan sudah dilakukan guru hanya saja belum dimaksimalkan dengan proses fukushuu .

Guru melanjutkan kegiatan pembelajaran dengan meminta siswa untuk membuka buku halaman 28. Guru menjelaskan tema pelajaran dekiru koto yang berarti hal yang dapat dilakukan. Guru melatih pengetahuan siswa dengan memberikan pertanyaan perbedaan antara kemampuan dan kesukaan. Karena tidak ada yang memahaminya, guru menjelaskan dengan bertanya kepada satu siswa. Tetapi siswa tidak menjawab. Memahami kebingungan siswa, 
kemudian guru menjelaskan tentang perbedaan hal yang disukai dan hal yang dapat dilakukan menggunakan bahasa Indonesia. Pada pembelajaran hari itu, langkah mengamati sudah dilakukan dengan memberikan contoh langsung dan membiarkan siswa secara aktif menemukan perbedaan hal yang dibandingkan guru.

Pembelajaran dilanjutkan dengan menjelaskan kosakata baru yang terdapat di buku. Guru menjelaskan arti kosakata tersebut. Selanjutnya siswa diperkenalkan pada pola kalimat untuk materi pada hari itu. Selama menjelaskan pola kalimat, siswa diberikan kesempatan untuk bertanya mengenai hal yang tidak dimengerti.

Karena tidak ada pertanyaan, siswa diminta membuat kalimat dengan pola kalimat tersebut. Tetapi, ketika siswa diminta membuat kalimat, banyak siswa yang tidak mengerti, sehingga dijelaskan kembali pola kalimat tersebut. Untuk membuat siswa lebih paham, diberikan beberapa contoh penggunaan pola kalimat tersebut. Pola kalimat terakhir yang diperkenalkan adalah pola kalimat bertanya yaitu "wakarimasu ka" dan cara menjawabnya. Pola kalimat ini dijelaskan dengan bertanya kepada siswa apakah mereka mengerti suatu bahasa asing. Pola kalimat yang terakhir diperkenalkan adalah pola donna gaikokugo ga wakarimasuka yang artinya mengerti bahasa asing apa?

Setelah semua pola kalimat selesai dijelaskan, siswa diminta membuat dialog percakapan. Setelah siswa berdiskusi selama 10 menit, masing-masing pasangan diminta untuk presentasi ke depan kelas. Tidak semua siswa maju pada hari itu karena jam pelajaran sekolah telah berbunyi. Pada tahap ini langkah mengasosiasi dan mengomunikasikan sudah coba diterapkan guru. hari itu. Pada kegiatan penutup, guru tidak melakukan refleksi dan kesimpulan dari materi pada hari itu. Pembelajaran ditutup dengan salam "Om shanty shanty shanty Om".

Observasi keempat dilakukan di kelas XII BB 2 pada tanggal 30 September 2017 dengan tema berekreasi. Ketika guru memasuki kelas, siswa mengucapkan salam "Om Swastyastu" dan dilanjutkan mengucapkan salam selamat pagi dalam bahasa Jepang yaitu "Ohayou Gozaimasu" yang dipimpin oleh ketua kelas.

Guru tidak menggunakan media pembelajaran seperti gambar ataupun video. Karena siswa memiliki buku pelajaran, siswa diminta untuk membaca materi yang akan dipelajari. Kemudian guru memberikan cerita yang berkaitan dengan materi. Ilustrasi diberikan dengan bahasa Indonesia. Seperti kemanakah siswa pergi atau berlibur pada akhir minggu atau ketika hari libur. Meskipun belum maksimal, langkah mengamati sudah terjadi. Tetapi langkah menanya tidak ada setelah langkah mengamati.

Pembelajaran dilanjutkan dengan diberikan kosakata baru tentang nama-nama tempat dalam bahasa Jepang. Selanjutnya siswa diperkenalkan pada pola kalimat baru. Selama menjelaskan pola kalimat, siswa diberikan kesempatan untuk bertanya mengenai hal yang tidak dimengerti. Karena tidak ada pertanyaan, siswa diminta untuk berlatih pola kalimat tersebut dengan menjawab latihan yang ada di buku mereka. Karena tidak ada siswa yang bersedia ketika diminta menjawab latihan tersebut, siswa ditunjuk satu-persatu untuk melatih pola kalimat yang telah dijelaskan.

Selesai melatih pola kalimat tersebut, pelajaran dilanjutkan dengan diberikannya pola kalimat baru Seorang siswa ditunjuk untuk menjawab latihan yang diberikan. Setiap pola kalimat selesai dijelaskan, siswa diminta untuk melatih pola kalimat tersebut. Dalam pembelajaran yang berlangsung hari itu, langkah mencoba selalu diterapkan guru disetiap pola kalimat yang diperkenalkan.

Setelah semua pola kalimat selesai dijelaskan, siswa diminta membuat dialog percakapan. Siswa diberikan pengertian bahwa mereka dapat mengganti nama tempat ataupun kegiatan seperti yang mereka inginkan. Misalnya siswa diminta menuliskan nama tempat tempat biasa mereka pergi. Setelah siswa berdiskusi selama beberapa menit, masing-masing pasangan diminta untuk presentasi ke depan kelas. Secara bergiliran siswa yang sudah siap maju untuk mempresentasikan hasil percakapan yang dibuat. Dalam pembelajaran yang berlangsung hari itu, langkah mengasosiasi dan mengomunikasikan sudah dilakukan. 
Ketika seorang siswa ditunjuk dan ditanyai mengenai percakapan temannya, bel pelajaran berbunyi. Kemudian pembelajaran diakhiri dengan salam "Om shanty shanty shanty Om". Sama seperti pembelajaran pada kelas XII BB1, guru tidak melakukan refleksi ataupun kesimpulan dari materi pada hari itu.

Observasi pertama di SMAN 4 Singaraja dilakukan di kelas XII BB pada hari Kamis, 18 Agustus 2017 jam ke 3. Tema pelajaran pada saat itu adalah Shumi (hobi atau kegemaran). Siswa mengucapkan salam "Om Swastyastu" dan dilanjutkan mengucapkan "Ohayou Gozaimasu". Guru mempersiapkan media pembelajaran berupa power point. Setelah media pembelajaran siap, absensi siswa mulai dilakukan. Selanjutnya siswa diminta untuk membuka buku. Dilanjutkan dengan menyampaikan tujuan pembelajaran yang harus dicapai secara lisan. Proses fukushuu tidak terjadi.

Kegiatan inti diawali dengan guru meminta siswa untuk mengamati gambar yang ditampilkan pada power point. Kemudian guru bertanya tentang hobi apa yang dimiliki oleh seseorang yang ada pada gambar tersebut. Dalam kegiatan pembelajaran yang berlangsung hari itu, langkah mengamai dan menanya sudah dilakukan.

Sambil melihat absen, seorang siswa diminta untuk membaca dan mengartikan kalimat yang ditampilkan pada power point. Sesuai perintah guru, siswa yang namanya dipanggil membaca contoh kalimat yang ditampilkan. Selanjutnya guru mengartikan kalimat tersebut. Setelah siswa diberikan waktu untuk mencatat, siswa diminta melatih pemahaman mereka tentang pola kalimat yang mereka pelajari sesuai dengan contoh yang ada. Mengikuti perintah guru, siswa mengerjakan soal tersebut. Seperti latihan sebelumnya, nama siswa yang dipanggil menjawab pertanyaan. Setelah melakukan drill, guru meminta siswa untuk mengerjakan latihan soal yang ada pada buku pelajaran. Siswa mengerjakan latihan soal sampai jam pelajaran berakhir dan latihan ini dijadikan tugas. Pada pembelajaran hari itu, dapat dilihat bahwa langkah mencoba dalam 5M sudah dilakukan. Tetapi langkah mengasosiasi dan langkah mengomunikasikan belum terjadi.

Saat kegiatan penutup guru menanyakan kesimpulan pelajaran pada hari itu. Kemudian menunjuk seorang siswa dan siswa tersebut menyimpulkan materi pelajaran. Setelah itu guru merapikan media pembelajaran diikuti siswa yang merapikan buku. Setelah itu siswa memberi salam "Om shanty shanty shanty Om" dan berpamitan kepada guru untuk keluar kelas.

Observasi kedua di SMAN 4 Singaraja dilakukan di kelas X BB1 pada hari Senin, 28 Agustus 2017 jam ke 5. Materi pelajaran pada saat itu adalah perkenalan diri. Siswa mengucapkan salam "Om Swastyastu" dan dilanjutkan mengucapkan "Ohayou Gozaimasu". Setelah mengabsen siswa, dibantu siswa, guru menyalakan LCD Proyektor untuk mempersiapkan media pembelajaran berupa power point. Pembelajaran diawali dengan melakukan fukushuu tentang materi sebelumnya. Selanjutnya siswa bergantian mempraktikan perkenalan diri di depan kelas. Beberapa siswa yang belum paham masih diizinkan melihat pola kalimat.

Materi pelajaran dilanjutkan dengan cara memperkenalkan orang lain. Guru menjelaskan materi sambil menampilkan pola kalimat tentang cara memperkenalkan orang lain dan cara membacanya. Selanjutnya siswa diberi waktu untuk mencatat. Dalam proses pembelajaran hari itu, guru juga menggunakan video sebagai media pembelajaran. Pada pembelajaran hari itu, langkah mengamati dan menanya sudah diterapkan dalam kegiatan inti.

Selanjutnya guru meminta siswa untuk mempraktikan cara memperkenalkan orang lain dengan cara memperkenalkan teman yang duduk di samping mereka. Materi pelajaran dilanjutkan dengan diperkenalkannya angka 1-10 dalam bahasa Jepang. Selanjutnya guru mempersilakan siswa untuk mencoba berhitung dengan bahasa Jepang. Setelah siswa paham, materi pelajaran dilanjutkan dengan cara memperkenalkan tingkatan kelas yang ditambah dengan nensei. Dilanjutkan dengan memperkenalkan beberapa kosakata dan pola kalimat untuk menyebutkan nama sekolah. Pada tahap ini, langkah mencoba dalam 5M sudah diterapkan dalam pelajaran bahasa Jepang. 
Selanjutnya, guru meminta siswa untuk berlatih membuat kalimat pada buku tulis. Guru memberikan soal yang disusun secara acak kemudian siswa diminta menyusun kalimat tersebut dengan benar. Selama mengerjakan latihan, bel pelajaran berbunyi dan soal tersebut selanjutnya dijadikan tugas. Pelajaran ditutup dengan memberikan kesimpulan yang diwakilkan oleh seorang siswa. Kemudian siswa berdiri dan memberikan salam sebelum meninggalkan kelas.

Observasi ketiga di SMAN 4 Singaraja dilakukan di kelas XI BB2 pada hari Selasa, 29 Agustus 2017 jam ke 7. Materi pelajaran pada saat itu adalah shigoto (pekerjaan). Siswa mengucapkan salam "Om Swastyastu". Setelah mengabsen siswa, dengan bantuan siswa, guru menyalakan LCD Proyektor untuk mempersiapkan media power point. Selanjutnya guru melakukan kegiatan fukushuu.

Kegiatan inti pembelajaran diawali dengan meminta siswa untuk mengamati gambar yang ditampilkan pada power point. Selanjutnya siswa diminta menyebutkan jenis pekerjaan yang ada pada gambar tersebut menggunakan bahasa Indonesia. Setelah menyebutkan jenis pekerjaan dalam bahasa Indonesia, gambar kembali diperlihatkan kemudian guru menjelaskan pekerjaan tersebut menggunakan bahasa Jepang. Sambil gambar diperlihatkan, siswa diminta untuk mengingat bahasa Jepang dari kosakata tentang jenis-jenis pekerjaan.

Pembelajaran dilanjutkan dengan mengamati video yang diputar. Sebelum video diputar, ditampilkan beberapa daftar pertanyaan yang harus siswa jawab. Satu persatu siswa ditunjuk untuk membaca pertanyaan tersebut. Karena ada kesalahan baca, guru membantu siswa membaca tulisan kana tersebut. Selanjutnya siswa diminta mencatat daftar pertanyaan tersebut. Siswa diberi waktu sekitar 5 menit untuk mencatat. Setelah itu, video berdurasi sekitar 1 menit diputarkan 3 kali agar siswa dapat memahami isi video tersebut. Dalam video tersebut diperlihatkan tentang dua orang (laki-laki dan perempuan) yang bercakap-cakap tentang keluarga masing-masing.

Selesai video diputar, siswa diminta menjawab pertanyaan yang telah diberikan guru. Seorang siswa ditunjuk dan diberikan masing-masing satu pertanyaan. Tetapi banyak siswa yang salah memahami isi dari video tersebut. Kemudian siswa diberikan penjelasan mengenai nama tokoh-tokoh dalam video tersebut dan video diputarkan kembali dan siswa diminta untuk menjawab pertanyaan yang diajukan sesuai dengan video. Dalam kegiatan pembelajaran hari itu langkah mengamati sudah terjadi. Langkah menanya dan mencoba juga sudah diterapkan dalam pembelajaran tersebut. Langkah ini diterapkan dengan guru mengajukan pertanyaan dan siswa mencoba menjawab pertanyaan yang diberikan yang berkaitan dengan video.

Kegiatan pembelajaran dilanjutkan dengan membahas soal secara satu persatu. Guru menjelaskan setiap pertanyaan yang tidak dimengerti siswa sambil sesekali memutar ulang kembali video. Selama membahas soal, bel akhir pelajaran berbunyi. Guru mengakhiri pelajaran dengan menyimpulkan kegiatan pembelajaran yang dilakukan hari itu.

Dalam pelaksanaan standar proses yang diatur dalam Permendikbud No. 65 Tahun 2013, proses pembelajaran dibagi menjadi 3 yaitu perencanaan pembelajaran, kegiatan pembelajaran dan penilaian. Perencanaan pembelajaran dalam Kurikulum 2013 meliputi silabus dan penyusunan Rencana Pelaksanaan Pembelajaran (RPP). Karena silabus telah dikembangkan oleh pemerintah, guru mata pelajaran hanya perlu menyusun RPP yang sesuai dengan silabus dan menyiapkan media pembelajaran yang diperlukan. Berdasarkan hasil penelitian, diketahui bahwa guru mengalami kendala dalam penyusunan RPP yaitu, menentukan model pembelajaran, merancang langkah pembelajaran $(5 \mathrm{M})$, dan menyiapkan media pembelajaran.

Berdasarkan hasil penelitian, diketahui bahwa guru mengalami kendala dalam menentukan model pembelajaran yang akan diterapkan di dalam kelas. Sesuai dengan Permendikbud No. 81A tentang Implementasi Kurikulum 2013 Tahun 2013 disebutkan bahwa model pembelajaran yang digunakan dalam Kurikulum 2013 adalah model inquiry, discovery, Problem Based Learning, dan Project Based Learning. Tapi dalam pelaksanaannya, model pembelajaran tersebut belum bisa diterapkan secara maksimal. 
Kendala lainnya yang dihadapi guru bahasa Jepang pada perencanaan pembelajaran adalah merancang langkah pembelajaran dengan pendekatan scientific. Dalam Permendikbud Nomor 65 tentang Standar Proses Pendidikan Dasar dan Menengah tahun 2013 disebutkan bahwa dalam penyusunan RPP, RPP yang disusun harus melibatkan partisipasi aktif peserta didik dan juga berpusat pada peserta didik untuk mendorong semangat belajar, motivasi, minat, kreativitas, inisiatif, inspirasi, inovasi dan kemandirian. Tapi dalam kenyataannya, menyusun RPP dengan prinsip seperti ini belum sepenuhnya dapat dilakukan oleh guru bahasa Jepang. Guru belum sepenuhnya dapat menyusun RPP yang mendorong siswa aktif dalam pembelajaran.

Selanjutnya, dalam perencanaan pembelajan, guru mengalami kendala dalam menyiapkan media pembelajaran. Dalam Permendikbud No. 65 Tahun 2013 disebutkan bahwa selain menyusun RPP, dalam perencanaan pembelajaran juga harus memperhatikan media pembelajaran Dari hasil wawancara diketahui bahwa guru mengalami kendala untuk menyiapkan media pembelajaran yang kreatif dan menarik untuk setiap pertemuan. Media pembelajaran yang biasa beliau gunakan adalah power point, tapi beliau tidak selalu menggunakannya karena keterbatasan waktu yang dimiliki guru untuk membuat media pembelajaran.

Pelaksanaan pembelajaran yang sesuai dengan Kurikulum 2013 berdasarkan Permendikbud No. 65 tahun 2013 dan Permendikbud No. 81A tahun 2013 terdiri dari 3 kegiatan yaitu, kegiatan pendahuluan, kegiatan inti, dan penutup. Dalam lampiran tersebut dijelaskan bahwa sebelum memberikan materi baru, guru sebaiknya menjelaskan tentang tujuan pembelajaran yang akan dicapai. Selanjutnya diharapkan agar guru menyampaikan cakupan materi yang akan dipelajari.

Setelah kegiatan pendahuluan, pembelajaran dilanjutkan dengan kegiatan inti. Kegiatan inti yang sesuai dengan Kurikulum 2013 dilaksanakan dengan pendekatan scientific sesuai dengan lampiran Permendikbud No. 81A tahun 2013. Pendekatan scientific merupakan pendekatan yang diimplementasikan dengan langkah $5 \mathrm{M}$ yaitu mengamati, menanya, mencoba, mengasosiasi dan mengomunikasikan. Berdasarkan hasil penelitian dapat diketahui bahwa langkah dalam $5 \mathrm{M}$ belum dapat diterapkan secara maksimal.

Menurut Anwar (2014) fokus utama dalam pembaharuan kurikulum lama menjadi Kurikulum 2013 ialah mendorong siswa agar menjadi lebih aktif. Tetapi dalam pelaksaannya, hal ini belum dapat diwujudkan. Kenyataanya, guru mengalami kendala untuk menjadikan siswa agar lebih aktif dalam kegiatan pembelajaran.

Selain kendala di atas, sumber belajar juga menjadi salah satu kendala yang dihadapi guru. Buku yang digunakan dalam pembelajaran bahasa Jepang masih buku yang lama dan jumlah buku yang tersedia belum mencukupi kebutuhan siswa. Banyak siswa yang belum mempunyai buku pegangan sehingga mereka kesulitan dalam proses belajar.

Setelah pelaksanaan pembelajaran, dilanjutkan dengan penilaian. Penilaian dalam Kurikulum 2013, diatur dalam lampiran Permendikbud No.66 tentang Standar Penilaian tahun 2013. Dalam penelitian yang dilakukan, guru mata pelajaran bahasa Jepang mengakui kendala utama yang dihadapi dalam implementasi Kurikulum 2013 ada pada standar penilaian.

Dari hasil penelitian yang dilakukan, diketahui bahwa guru mengalami kendala dalam penilaian aspek sikap yang sesuai dengan tuntutan Kurikulum 2013. Dalam penilaian sikap, dibagi menjadi 2 sikap yang dinilai yaitu spiritual dan sosial. Karena banyaknya jenis penilaian dan terbatasnya waktu, dalam proses penilaian guru bahasa Jepang belum dapat melakukan penilaian yang sesuai dengan Kurikulum 2013 yang telah diatur dalam lampiran Permendikbud No.66 tentang Standar Penilaian tahun 2013.

\section{Simpulan dan Saran}

Berdasarkan hasil penelitian yang dilakukan mengenai kendala implementasi Kurikulum 2013 di SMAN 2 Singaraja dan SMAN 4 Singaraja, dapat ditarik kesimpulan sebagai berikut. 
Pertama, berdasarkan hasil penelitian diketahui kendala yang dihadapi guru bahasa Jepang antara lain, (1) menciptakan pembelajaran yang berpusat pada siswa. Dari observasi yang dilakukan terlihat guru masih menjadi center dalam pembelajaran tersebut, sedangkan siswa kebanyakan diam atau menunggu perintah guru, (2) guru kesulitan memilih model pembelajaran. (3) menyiapkan media pembelajaran. (4) merancang langkah pembelajaran. Guru mengalami kendala dalam merancang langkah pembelajaran yang dapat membuat siswa menjadi aktif di kelas, (5) buku sumber yang terbatas. (6) menerapkan pendekatan scientific. Dari hasil penelitian yang dilakukan, diketahui langkah $5 \mathrm{M}$ dalam pembelajaran bahasa Jepang belum terlaksana secara maksimal. (7) dan menerapkan sistem penilaian yang sesuai dengan Kurikulum 2013. Banyaknya jenis penilaian dan jumlah siswa yang banyak menjadi kendala utama guru dalam melakukan asesmen dengan cara Kurikulum 2013.

Kedua, faktor yang menyebabkan kendala dalam mengimplementasikan Kurikulum 2013 didasari oleh beberapa hal. Faktor-faktor tersebut antara lain penggunaan media pembelajaran, ketersediaan sarana prasarana, kesiapan guru, keterbatasan pengetahuan bahasa Jepang yang dikuasai siswa, karakteristik siswa yang berbeda-beda, banyaknya jumlah siswa, kurang aktifnya siswa, keterbatasan waktu, guru terbiasa mengajar dengan kurikulum lama, banyaknya jenis asesmen yang ada pada Kurikulum 2013 dan beban kerja guru yang besar.

Ketiga, upaya yang dilakukan guru untuk mengatasi kendala yang dihadapi adalah berusaha menerapkan pembelajaran yang sesuai dengan konsep Kurikulum 2013, mencari materi di buku sumber yang sesuai dengan silabus, menyiapkan power point untuk siswa, melakukan penilaian kepada siswa yang berbeda di setiap pertemuan.

Berdasarkan kesimpulan yang telah disampaikan, maka terdapat saran pada beberapa pihak terkait, agar lebih baik lagi di masa yang akan datang. Saran tersebut adalah sebagai berikut.

1. Bagi guru atau pendidik

Dengan adanya penelitian ini diharapkan guru dapat meningkatkan kualitas pembelajaran dengan menerapkan pendekatan scientific, model pembelajaran yang dianjurkan Kurikulum 2013 dan memanfaatkan media pembelajaran sehingga proses pembelajaran di kelas berjalan sesuai standar Kurikulum 2013. Guru diharapkan menambah wawasan dan lebih aktif untuk mengenal Kurikulum 2013 melalui media-media informasi maupun mempelajari buku-buku Kurikulum 2013. Diharapkan guru mau membuka diri untuk melakukan perubahan yang lebih baik untuk meningkatkan mutu pendidikan.

2. Bagi Pihak Sekolah

Adanya penelitian tentang implementasi Kurikulum 2013 dalam proses pembelajaran bahasa Jepang dapat dijadikan bahan kajian lebih serius oleh pihak lembaga agar implementasi Kurikulum 2013 sesuai dengan tujuan pembelajaran. Pihak sekolah hendaknya melakukan evaluasi secara berkesinambungan tentang penerapan Kurikulum 2013. Selain itu, menyiapkan semua komponen pembelajaran mulai dari silabus, buku pedoman guru, buku pegangan peserta didik, fasilitas pembelajaran, kondisi sarana dan prasarana pembelajaran juga perlu diperhatikan oleh pihak sekolah agar implementasi Kurikulum 2013 dapat berjalan sesuai dengan standar Kurikulum 2013.

3. Bagi Peneliti lainnya

Diharapkan dengan adanya penelitian terkait kendala implementasi Kurikulum 2013 dapat menjadi perbandingan untuk peneliti lain yang ingin melakukan penelitian terkait implementasi Kurikulum 2013. Peneliti lain dapat melakukan penelitian yang berhubungan dengan kendala Kurikulum 2013 misalnya pada sekolah dengan jenjang berbeda.

\section{Daftar Pustaka}

Anwar, Rusliansyah. 2014. "Hal-hal yang Mendasari Penerapan Kurikulum 2013". Humaniora, Volume 5, Nomor 1 (hlm. 97-106). 
Panikar, Prakrthi, dkk. 2014. "Best Practices in Curriculum Development \& Delivery with special reference to Educational \& Professional Development Department at Caledonian College of Engineering, Oman". International Journal of Education and Research, Volume 3, Nomor 4, (hlm. 366).

Peraturan Menteri Pendidikan dan Kebudayan Republik Indonesia No. 159 Tahun 2014 tentang Evaluasi Kurikulum. Jakarta: Kementerian Pendidikan dan Kebudayaan.

Peraturan Menteri Pendidikan dan Kebudayan Republik Indonesia No. 81A Tahun 2013 tentang Implementasi Kurikulum. Jakarta: Kementerian Pendidikan dan Kebudayaan.

Peraturan Menteri Pendidikan dan Kebudayaan Republik Indonesia Nomor 65 tahun 2013 tentang Standar Proses Pendidikan Dasar dan Menengah. Jakarta: Kementerian Pendidikan dan Kebudayaan.

Rahayu, Syah Bania Puji. 2015. Analisis Kesulitan Guru Bahasa Jepang dalam Mengimplementasikan Kurikulum 2013. Skripsi. Jurusan Bahasa dan Sastra Asing, Fakultas Bahasa dan Seni, Universitas Negeri Semarang.

Satori, Djam'an dan Aan Komariah. 2011. Metodologi Penelitian Kualitatif. Cetakan Ke-3. Bandung: Penerbit Alfabeta.

Undang-Undang Republik Indonesia no. 20 Tahun 2003 tentang Sistem pendidikan Nasional. 2003. Jakarta: Depdiknas.

Yani, Ahmad. 2014. Mindset Kurikulum 2013. Bandung: Alfabeta. 